\title{
Neki ključni vidici selilaštva i izbjeglištva u Svetom pismu
}

Niko Bilić*

\begin{abstract}
Sažetak
Kako Biblija gleda na suvremenu europsku temu migracija? Nakon napomene o hodočasničkom značaju Božjega naroda, Abraham (Post 12) upozorava na blagoslivljanje kao svrhu, a odmak od oholosti i nerazumijevanja kao uzrok migracije. Jakovljev primjer ističe povratak (Post 35) koji, nakon osobne lustracije, obnavlja izvorni nacrt čovjeka iz Post 1. Selilaštvo i izbjeglištvo Svete Obitelji pokazuje napokon da se i u tom otkriva način kako prihvatiti Otkupitelja..
\end{abstract}

Ključne riječi: Isusovačka služba za izbjeglice; razlog migracija; povratak; narod Božji; Abraham; Jakov; Sveta Obitelj

\section{Uvod}

Ovo istraživanje toga što Pismo kaže o seliocima i izbjeglicama započinjemo u čas dok na lokalnoj razini traje mnoštveno iseljavanje iz Hrvatske, a ključni uzrok nije tek materijalne i gospodarske naravi, nego nepoštovanje dostojanstva ljudske osobe te gubitak povjerenja u pravosudnu, zakonodavnu i izvršnu vlast. Hrvatska je po prirodnim bogatstvima vrlo, vrlo poželjna za život, pa su razlozi za selidbu i suvremeno izbjeglištvo među nama ljudima. Kada govorimo o seliocima u Svetom pismu, govorimo dakle i o našem vlastitom problemu, što još jednom dokazuje drevno iskustvo da Biblija ne govori tek o dalekoj prošlosti i drugom svijetu, nego se nas tiče. Osim toga, na globalnoj razini svakako imamo na umu da je zbog vjere 2018. godine ubijeno više od 3.000 kršćana, te da ih je progonjeno oko 300 milijuna (Hrvatski program Vatikanskog radija, 2018), što i dalje — paradoksalno — kršćansku vjeru čini najprogonjenijom na svijetu i pokazuje kako smo daleko od Kristova Kraljevstva.

* Doc. dr. sc. Niko Bilić, Fakultet filozofije i religijskih znanosti Sveučilišta u Zagrebu. Adresa: Jordanovac 110, 10000 Zagreb, Hrvatska. E-adresa: nbilic@ffrz.hr. Ovaj je rad izmijenjeno i dopunjeno predavanje koje je održano u Zagrebu 30. studenoga 2018. na međunarodnoj konferenciji uz 25. godišnjicu JRS Hrvatska Primiti, zaštititi, promicati, integrirati. Znanstveni skup organizirali su Isusovačka služba za izbjeglice JRS i Fakultet filozofije i religijskih znanosti Sveučilišta u Zagrebu. 
Papin poziv cijeloj Crkvi da smo dužni primiti, zaštiti, promicati i integrirati odnosi se na Kristov posao, na koji se kod nas, poštujući zakonitost, u posljednjih četvrt stoljeća velikodušno dala Isusovačka služba za izbjeglice (JRS). To što papa Franjo traži u srži je kršćanske vjere i ponajprije zahtijeva od nas da sebe i svoje kao prvi Božji dar i zaduženje primimo, zaštitimo, do kraja prionemo uz Krista Otkupitelja i integriramo se u njegovu Crkvu — mistično Tijelo. Pritom smo obvezni promicati Evanđelje, koje osobito smjera na obespravljene, one "na periferiji" — kako od početka govori papa Franjo — ponajprije u vlastitoj sredini. U Hrvatskoj smo danas osobito svjesni kako je naš blaženik, kardinal Stepinac, u divljem vihoru svjetskoga rata spašavao brojne ljudske živote pred masovnim ubijanjem, a kakvo smo izbjeglištvo iskusili i koliko smo mi učinili za prognanike u Domovinskom ratu, snažno živi u pamćenju.

\section{Hodočasnički Božji narod}

Ugodna je zadaća ovoga napisa uputiti smiren, dubok pogled na blago koje nam je povjereno, na priznatu i prokušanu Riječ Božju, u kojoj možemo naći orijentir i nadahnuće. Rad započinje s jasnih polazišta. U kršćanskoj je svijesti ono što Crkva od početaka prepoznaje, gledajući na svoj hodočasnički identitet (LG 2,9). Stari zavjet opisuje Božji narod, koji je bio na putu u više navrata. Novi zavjet pak kršćanski život i nasljedovanje Krista naziva Putom (grč. he hodós, hrv. hod), prvi put u čuvenu izvještaju o obraćenju sv. Pavla, koji je legalistički, s poveljama pribavljenima od vlasti na vlastitu inicijativu, zadahnut mržnjom, krenuo u pohod na sve koji pripadaju Putu (Dj 9,2). ${ }^{1}$ Kapitalna promjena koja ga je dovela upravo u Damask, kamo je i pošao, potječe u svemu od osobe Isusa Krista uskrsnuloga, a očituje se u tom da Pavao umjesto uhićenja javno proglašava, sa svojih svetopisamskih stajališta stroge farizejske sljedbe, da je Isus Sin Božji (Dj $9,20)$ i da je Mesija $(9,22)$.

Isusov izvorišni poziv traži pokret, hod: "Slijedi me!" (grč. akolouthéo, npr. Mt 8,$22 ; 9,9 ; 19,21 ;$ Iv 1,43; 21,19), što papa Franjo od početka svojega pontifikata posebice voli isticati. "Idite!" (npr. Mt 7,13; 9,13; 10,6; 11,4; 21,2; 26,18; $28,10.19)$ šalje Gospodin svoje učenike, pokazujući kako je novozavjetni narod Božji u svojim temeljima narod na putu do punine Kraljevstva Božjega. Petrova poslanica Kristove vjernike promatra kao "pridošlice" (1 Pt 2,11), ${ }^{2}$ a Pavao inzistira da je "naša domovina na nebesima" (Fil 3,20).

Da bismo u ovom radu postupili sustavno, istaknimo unaprijed kako je u Svetom pismu Božji narod živio i u tuđini i u domovini. Lako je uočiti kako je prvu definiciju dobio dok se je još nalazio u "Kući ropstva" ('ami "moj narod" Izl 3,7.10), ${ }^{3}$

1 Grčka riječ he hodós ("put”) prvi put se u Dj 9,2 rabi kao oznaka za kršćansku Crkvu i njezino učenje, potom još u Dj 19,9.23; 22,4; 24,14.22, a pripada isključivo jeziku Lukina djela (Fitzmyer, 2008, 423).

2 Nije samo usporedba, nego adresati jesu pridošlice i stranci, već u 1 Pt 1,1.17 (Elliott, 2008, 457).

3 Dugo vremena Gospodin promatra muku svojega naroda (Durham, 2002, 32). 
a kad su jednom, uz lutanje i rogoborenje, dospjeli u svoju domovinu (Jš), baštinu koju im je Bog dao, opet su je svojim lošim potezima izgubili i završili u izgnanstvu (2 Kr 25). Blagoslovljeni povratak u domovinu i velika obnova (Ezr/Neh), uvelike znači prihvaćanje strane vlasti, kako je ostalo i u vrijeme Kristovo.

Imajući na umu da je Božji narod u Petoknjižju, ishodišnom dijelu Biblije, pretežito narod selilaca, štoviše unutar tih prvih pet knjiga ni ne ulazi u svoju domovinu, u ovom radu pođimo redom. Pogledajmo najprije početak, tj. čuveni Božji poziv Abrahamu, praroditelju Božjega naroda (Post 12). Zaustavimo se zatim na praocu Jakovu, kojega nam Pismo u njegovu bijegu od obitelji i potom povratku u domovinu (Post 35) pokazuje kao izbjeglicu i selioca. U završnom dijelu rada pogledajmo napokon evanđeoski izvještaj o Svetoj Obitelji, koja u svojoj povijesti sažima selilaštvo i izbjeglištvo svekolikoga Božjega naroda (Mt $2,13-23){ }^{4}$

U istraživanju nas, razumljivo, osobito zanima koji je uzrok za migracije, kako ga Sveto pismo prikazuje, potom, možemo li prepoznati svrhu koju u fenomenu selilaštva i izbjeglištva Biblija nudi. Bez teškoća ćemo također uočiti kako Pismo ističe važnost povratka. Pred novom seobom naroda u 3. mileniju kršćanstva, koja je već započela, što iz političkih, što iz ekonomskih ili klimatskih razloga, ovaj rad želi dati svoj, koliko god skroman, prinos, tražeći pravi odgovor — odgovor Evanđelja, odgovor Krista, Učitelja i Spasitelja — na zadaće koje stoje pred nama.

\section{Abraham i Božji "projekt"}

Listamo li Sveto pismo od početka, možemo se zaustaviti na čuvenom pozivu praocu Abrahamu: »Idi iz svoje zemlje i svojega roda i očinske kuće!« (Post 12,1), kao prvom primjeru iseljavanja. Istina, već Post 3,245 izvješćuje o čovjeku kako je u početcima bio protjeran (hebr. grš), ali tu još nije riječ o bitnom društvenom kontekstu. Kod Kaina pak, koji se buni da ga Bog izgoni (hebr. gř̌, Post 4,14 , usp. Jon 2,5), ${ }^{6}$ nećemo naći potvrde da je to istina, jer Kain sam odlazi ispred lica Božjega $(4,16)$. Daleko nam je zanimljivija plauzibilna naznaka da su čovjekova egzistencijalna nestalnost i povijesni nemir, neprestane migracije, posljedica bratoubojstva i nesređenoga odnosa s bližnjim. Zato što je bratu život oduzeo, Kain je osuđen na lutanje: 1 . fizičko lutanje u "zemlji lutanja" koja nosi upravo ime Nod (hebr. "lutanje”, Post 4,12.14.16; Wenham, 2002a, 110); 2. psihičko lutanje koje se očituje u uskipjelu bijesu kao počelu djelovanja te u strahu od ubojstva koje je sam bio počinio i uveo u biblijsku povijest (hebr. hrg, Post

4 Vezu sa Starim zavjetom potvrđuje forma teksta jer tri dijela perikope svaki put završavaju citatom: Hoš 11,1; Jr 31,15; Iz 11,1 (Hagner, 2002, 33).

5 Taj glagol u Petoknjižju opisuje protjerivanje stanovnika Kanaana (Wenham, 2002a, 85).

6 Iz Jonina je primjera očito kako on samo subjektivno tvrdi da ga je Bog odbacio (Stuart, 2002, 476). 
4,8.14); 3. spoznajno lutanje kad lažno tvrdi da ga Bog izgoni $(4,14)$, a već prije izbjegava odgovor o bratu $(4,9)$.

\subsection{Abrahamov lik}

Prije nego promotrimo pojedinosti kod Božjega poziva Abrahamu, valja podsjetiti na nesporno tumačenje kako se u liku Abrahama na putu u Kanaan ujedno sažimlje povijesni put povratnika iz babilonskoga izgnanstva. Abraham, koji još nije imao posjeda u Svetoj zemlji u koju ga je Bog vodio, slika je Božjega naroda koji bijaše protjeran pod Nabukodonosorom za pada Jeruzalema 587. pr. Kr, a potom se u skladu s Izaijinim proroštvom o Novom izlasku (Iz 43,19) za Kirove vladavine vratio u domovinu. ${ }^{7}$ Proslava blagdana sjenica u Neh 8 , prvi put takva nakon Jošuina vremena (r. 17), izvrsno upućuje na biblijsku misao da je riječ o novom ulasku u Obećanu zemlju. Također, u Neh 8 prepoznaje se zasnivanje suvremenoga židovstva. Za novozavjetnu perspektivu važan je i prvi Jošuin ulazak i ovaj drugi ulazak povratnika u Obećanu zemlju, opisan u Knjizi Nehemijinoj, jer oba zacrtavaju tumačenje o narodu Božjem koji pod vodstvom Mesije, Spasitelja Isusa, putuje prema vječnoj Obećanoj domovini. Abraham je pralik i prva najava toga putovanja.

\subsection{Božji poziv u obiteljskoj povijesti}

Ako je Post 12 ishodišni biblijski pogled na selilaštvo, uočimo ponajprije da nije riječ o ljudskom planiranju ni o prikrivenom zavojevačkom nacrtu. U skladu s osnovnim biblijskim imperativom, Abraham sluša poziv koji dolazi od Boga. Bog traži izlazak i napuštanje domovine. Uočimo nekoliko relevantnih činjenica u Post 12. Božji poziv Abrahamu dolazi u bitnom trenutku osobne životne povijesti kad mu je otac Terah umro (Post 11,32), te je poziv na pokret ujedno poziv na odraslu samostalnost kao svrhu odgoja. ${ }^{8}$ Uloga oca u Bibliji redovito je istaknuta, sukladno općeljudskomu iskustvu. Abraham preuzima odgovornost za sebe i cijelu širu obitelj. Postaje voditelj zajednice.

Otac je važan i stoga što je već Terah, prije očitovanja Božjih nakana, cijelu obitelj poveo na isti taj put (Post 11,31$).{ }^{9}$ On je voditelj koji je sa sobom uzeo i sina Abrahama i unuka Lota i Abrahamovu ženu na putovanje u Kanaan, pa su iz prapostojbine Ura već stigli do Harana, gdje je Abraham doživio poziv. Dobrohotni Božji naum djeluje unaprijed. Abrahamov odlazak do Obećane zemlje nije protestno odvajanje od očinskoga puta, nije prevratničko nasilno gaženje prošlosti, nego nastavak putovanja koje je otac započeo.

Božji poziv Abrahamu ne upućuje na osvajački pohod mladića u punoj snazi gledamo li na Abrahamovu dob od 75 godina (Post 12,4), kojom je već premašio prosjek od psalamskih 70 godina (Ps 90,10), te bi s pravom mogao poželjeti

7 Bog se zato služi perzijskom političkom i vojnom moći (Watts, 2005, 677).

8 Prema Samaritanskoj Tori Abraham polazi iz Harana u godini Terahove smrti (Speiser, 2008, 79).

9 Terahovi razlozi se ne navode (Wenham, 2002a, 273). 
smirenje i dovršetak, a ne novi pokret koji Bog zahtijeva. Istina, odaziv na Božji poziv, donio mu je novu puninu života, biblijskih stotinu godina (Post 25,7; Wenham, 2002b, 160). Zahtjev koji Bog postavlja, napokon, ne traži preuzetan put "preko svijeta", jer cilj postavljen u Post 12,1, svega nekoliko redaka kasnije Abraham je već dosegnuo: »stigli su u Kanaan« (r. 5).

\subsection{Metoda, svrha i uzrok migracije}

Ključ za razumijevanje Abrahamova iseljavanja u impliciranu je pozivu na pažljivo promatranje Božjega vodstva. Abraham ne dobiva unaprijed podatke, nema odredište na raspolaganju. Božji poziv »Idi!« (Post 12,1) odnosi se na cilj koji će mu - u glagolu na kraju rečenice, koji se redovito shvaća kao futur Bog tek pokazati (»pokazat ću ti« hebr. r’h hifil, impf. sa sufiksom za 2. 1. jd.; usp. Wenham, 2002a, 266). Abrahamova je zadaća njegovati povezanost s Bogom i motriti kamo ga Bog vodi. Već ovdje, u početku Abraham se pripravlja za onaj teološki, kontemplativan pogled u visine (»Pogledaj!« hebr. nbț hifil, imperativ, Post 15,5), na koji ga je Bog pozvao i koji je neposredno prethodio njegovoj vjeri (r. 6). ${ }^{10}$ Je li pretjerano već ovdje u pozivu Abrahamovu razaznati začetke duhovnoga rasuđivanja koji su se razvili i njegovali sve do u treće tisućljeće kršćanstva?

Abraham treba ići onamo kamo ga Bog vodi, ne proračun osobne lagodnosti ni zloban naum. U središtu Božje nakane budući je velik narod (hebr. gôj gādôl, Post 12,2$)^{11}$ i u tom se najbolje vidi kako Abraham ne može računati na svoje snage jer se otpočetka, otkako je sa Sarom, ističe da nemaju djece (Post 11,30) pa se moraju osloniti na Boga.

Glavno je u našem promatranju ipak uočiti svrhu, zašto Bog traži pokret u novi kraj, i prethodni razlog, uzrok, zbog kojega postavlja takav zahtjev. U pozivu Post 12,1b-3, koji spominje i »zemlju« (r. 1) i »narod« (r. 2) po jedanput, lako je uočiti središnju ulogu »blagoslova« koji se čak pet puta pojavljuje (hebr. brk 2x u r. 2; 3x u r. 3 v. Wenham, 2002, 275). ${ }^{12}$ Ono što Bog Abrahamu namjenjuje i što od njega zahtijeva bitan je korak u biblijskoj antropologiji. Sam Abraham treba biti blagoslov (Post 12,2b), a razmjeri toga blagoslova odgovaraju Božjim nakanama jer uključuju sve obitelji (mišpehot) na tlu zemaljskom ('adamâ Post 12,3). ${ }^{13}$ Prema Gal 3,8 univerzalan blagoslov naći će ostvarenje tek u Kristu.

Kod Abrahama se očituje kako Stvoriteljev naum s čovjekom nije samo da pasivno primi blagoslov (»blagoslovit ću te «, Post 12,2), kako to bijaše već kod stvaranja (Post 1,28; 5,2), zajedno s ostalim stvorenjima (Post 1,22; 2,3). Abraham je ujedno aktivni nositelj blagoslova: »Bit ćeš blagoslov « (Post 12,2); »Tobom će se blagoslivljati« (r. 3). Kao što Bog daje blagoslov, tako i čovjek, Božjim darom,

10 Riječ je o stjecanju povjerenja, pouzdavanju (Speiser, 2008, 112).

11 Na intrigantan način Bog obećava da će Izrael biti gôj među gôjim, svjetskim narodima (Hamilton, 1990, 372).

12 U pozivu Abrahamu blagoslov u Post 12,2s ima ukupan biblijski broj od 7 klauzula (Hamilton, 1990, 371).

13 Programatska izjava odnosi se na sve narode svijeta pobrojane u Post 3-11 (Hamilton, 1995, 374). 
treba blagoslivljati. ${ }^{14} \mathrm{U}$ tom se potvrđuje da je na sliku i priliku Božju. Svrha Abrahamova iseljavanja silan je zadatak: donositi blagoslov, ne razaranje i teror.

U Svetom pismu, koje iznimno cijeni izvore vlastitoga identiteta i vjernost početcima, još je zanimljivije pitati koji bi uzrok obrazlagao Abrahamovo napuštanje korijena, koje Bog od njega traži. Zacijelo će prva pomoć u otkrivanju odgovora biti dio Božjega obećanja da će Abrahamovo ime (hebr. šem, Post 12,2) učiniti velikim. To nam je uporište da u prethodnom kontekstu uočimo podjednaku nakanu graditelja zloglasne Babilonske kule: »Napravimo si ime!« (̌̌em, Post 11,4). ${ }^{15}$ Covjekova hlepnja da sam sebi pribavlja ime dodatno dokazuje kako je promašen taj ljudski projekt, nasuprot Božjemu projektu s Abrahamom. Čovjek naime od početka ima ime, od Boga darovano: on je 'Adam (hebr. »čovjek«, Post 5,2$)^{16}$ — dio zemaljskoga svijeta koji je Bog stvorio. Ime mu je u skladu s građom — zemljom ('adamâ, Post 2,7) — od koje je sazdan.

Da smo na pravom tragu kad otkrivamo vezu Božjega poziva Abrahamu (Post 12) s prethodnom izgradnjom Babilonske kule (Post 11) najbolje nam pokazuje lako utvrdiv podatak da je u biblijskoj povijesti Ur Kaldejski, iz kojega Abraham potječe - doslovce Ur Kaldejaca (hebr. kašdîm) - isto što i Ur Babilonski. ${ }^{17}$ Već izvještaj o opsadi Jeruzalema u 2 Kr 25,10 naziva babilonske osvajače "Kaldejcima”, a kod proroka, primjerice Jeremije, posve je uobičajeno tako govoriti. Osnovica za takvo ime zacijelo je činjenica da su istaknute vojne postrojbe babilonskoga carstva bili upravo Kaldejci. Problematičan grad i kula s vrhom do neba znana su slika temeljitoga povijesnoga stradanja 587. pr. Kr., kojemu se u Post 11 razotkrivaju začetci.

Zašto Abraham mora na put? Zato što Bog od njega traži korjenito odvajanje od oholosti, kojom čovjek prezirno zanemaruje zemlju, povjerenu mu na obrađivanje (Post 2,5.15) i čuvanje (Post 2,15), ${ }^{18}$ a preuzetno se želi uzdići u nebesa. Svojim silama želi stvarati vezu između zemlje i neba, koja već postoji (usp. duga, znak Saveza, s "glavom" u nebesima i "nogama” na zemlji, u Post 9,13; ljestve u Jakovljevu snu u Post 28,12). Abraham se treba udaljiti od nerazumijevanja koje je plod takve oholosti (Post 11,7.9) ${ }^{19}$ i očito se ne zasniva tek na, lako nadvladivim, lingvističkim i gramatičkim razlikama. Božji projekt odvaja Abrahama od ljudskoga projekta Babilonske kule.

14 Za razliku od pasivnoga tumačenja koje daju Dillmann, Procksch, i L. Schmidt s jedne strane, Keil, Delitzsch, Wolff i Westermann s druge strane ističu to aktivno značenje (Wenham, 2002a, 276).

15 Graditelji žele steći glasovitost i besmrtnu slavu, a postižu sramotno ime zbrke i zabune (Hamilton, 1995, 353 i 357), nalik na "bla-bla" u suvremenom izričaju.

16 Hebr. razlikuje između osobnoga imena i opće imenice s članom (Wenham, 2002a, 126).

17 Potvrdu nalazimo u činjenici da se u stotinama spomena na klinastom pismu Ur nigdje ne nalazi s imenom Kaldejaca i da tumači nisu jedinstvena mišljenja koji bi to Ur geografski bio (Hamilton, 1990, 364s). Kao i zemlja Šinear, tako i to ime, čini se, podsjetnik su na povijesno iskustvo propasti pod Babilonom.

18 Oba glagola sadrže i svoje bitno religijsko obilježje: služiti i obdržavati (Wenham, 2002a, 67).

19 Hebr. izvornik ukazuje na izravan preokret: Bog jezičnom zbrkom ( $n b l$, Post 11,7) izokreće ljudske cigle (lbn, 11,3) (Hamilton, 1990, 355). 
U Abrahamovu primjeru selilaštva za to je istraživanje napokon važan Savez koji Bog s njime sklapa u Post $15,18 .^{20}$ Sadržaj Saveza znakovit je jer Bog Abrahamovu potomstvu obećava zemlju od Rijeke u Egiptu sve do Eufrata. Božji promisao za život naroda ne isključuje mučna razdoblja kad nisu bili u domovini, nego bijahu robovi na Nilu, odnosno izgnanici na Eufratu.

\section{Jakov postaje novo stvorenje}

U potrazi za biblijskim pogledom na selioce i izbjeglice iduća čvrsta točka zacijelo može biti praotac Jakov, neposredni predak dvanaest plemena Izraelovih. Nije teško unaprijed uočiti da se u liku Jakova u isti mah razmatra iskustvo Božjega naroda, napose u odnosu sa susjedima. To je, primjerice, odmah raspoznatljivo u slučaju Edoma koji je Ezav, brat Jakova-Izraela.

Ako nam je kod Abrahama najvrjednije bilo gledati što je svrha radi koje kreće na put, i koji uzrok za njegovu migraciju stoji u pozadini, kod Jakova je već na prvi pogled naglasak drukčiji. Osobito nam pred oči dolazi važnost povratka. Ključno je vratiti se onamo kamo čovjek pripada, doći s poštovanjem natrag na očevinu, prekinuti bijeg, izmiriti se sa svojima. Taj je povratak teološki jednak prijeko potrebnomu obraćenju koje potom omogućava osobno sazrijevanje i ostvarivanje životne zadaće.

\subsection{Bog nalaže povratak}

Za našu svrhu vrijedi započeti promatranje Jakovljeva puta, takoreći, iz sredine, od prijelomnoga trenutka u Post 35. Gospodin upućuje zahtjev Jakovu da ustane i uziđe natrag u svoj zavičaj (Post 35,1). Istina, tu se ne rabi biblijska riječ šûb (hebr. "vratiti se", "obratiti se"), stručni izraz za obraćenje. Ali navedeni glagol 'alâ ("uziđi!") ${ }^{21}$ također je teološki obilježen, jer označava "put prema gore" odnosno "podizanje", te je osnovica za biblijski pojam žrtve paljenice, služi kao opis puta iz "Kuće ropstva" u Obećanu zemlju, i tijekom biblijske povijesti označava "hodočašće", vjerničko uzlaženje u Sveti grad.

Kao i kod Abrahama, Bog Jakovu daje zapovijed. To je vidljivo iz zahtjeva u Post 35,1, koji Jakov dosljedno prenosi cijeloj zajednici (»ustati«, »uzići« Post 35,1.3). Izvornu zapovijed Jakov je bio primio već u Post 31,3 (hebr. šûb). Nakon toga izvijestio je obitelj o Božjem glasniku koji mu je u snu (Post 31,11) prenio teološki sročen Gospodinov nalog. Jakov je pozvan na izlazak (hebr. jṣ̣') i povratak (hebr. šûb) u domovinu: »Iziđi iz ove zemlje i vrati se u zemlju svojega roda!« (Post 31,13).22

20 Odstupamo od redovita tumačenja koje prepoznaje veličinu Davidova kraljevstva, čitajući umjesto Nila Wadi el Ariš (Hamilton, 1990, 438).

21 Značenje je topografski ispravno jer je Betel oko $500 \mathrm{~m}$ iznad Šekema (Hamilton, 1995, 374).

22 Nakon prve zapovijedi u Post 31,3, nalog u snu uz povratak pridodaje napuštanje (Hamilton, 1995, 289). 
Božji poziv na povratak u Post 35,1 relevantan nam je ponajprije zato što u Jakovljevoj osobnoj povijesti označava presudan korak naprijed. On počinje slušati Božji glas. U početcima, za velike prijevare kojom je pred ocem nijekao vlastiti identitet, majka je Jakova iz svojih razloga, povezanih s viđenjem, vodila i podržavala. Triput si je pritom preuveličano pripisivala božanski autoritet biblijskom formulom: »Poslušaj moj glas! (Post 27,8.13.43). Sin Jakov u okviru pohlepne laži, na loš je način bio podložan ljudskoj vlasti. Potom doživljava čudesan san u kojemu prvi put doduše čuje Božji glas (Post 28,13-15), ali na temelju Jakovljeva odgovora u Post 28,20-22 ne prepoznajemo da ga je i poslušao. Ostaje u razumljivim egzistencijalnim interesima (hrana, odijelo, zaštita), ${ }^{23}$ a Božje širokogrudne nacrte o zemlji, potomstvu i blagoslovu uopće ne uzima u obzir.

Posluh naredbi Božjoj koja od njega traži povratak nakon dugogodišnjega izbivanja i pečalbe znači da je Jakov počeo provoditi ono što Bog od njega traži. Napustio je svoje metode trgovanja i prijevare s kojima je započeo kao lovac na blagoslov. Nije više pod izvitoperenim tuđim diktatom, nego poštuje Božje nakane.

\subsection{Blagoslov u domovini}

Vrhunski argument u našem promatranju pruža zasigurno opis u Post 35,9.10. Tek tu, vrativši se, kad je poslušao Božju zapovijed, u domovini, Jakov dobiva željeni blagoslov, koji je od početka tražio. Dva biblijska retka Post 35,9s upozoravaju ponajprije na važan pedagoški postupak: ponavljanje. Prvo ponavljanje i potvrda jest blagoslov koji tu u zavičaju Bog daje Jakovu (hebr. brk, Post 35,9). Pouka je jasna. Što je na početku prijevarom Jakov htio iznuditi (Post 27), najprije je sam uvidio da ne vrijedi kad u boju s Bogom još uvijek traži blagoslov (Post 32). Što potom nastoji bitkom prisilno steći (»Neću te pustiti«, Post 32,27), sada jasno prima kao dar koji Bog iz ljubavi daje. Ne može se ni prijevarom ni vlastitom bitkom do njega. Bog na svoju inicijativu, tu na rodnoj grudi, blagoslivlja Jakova.

Kao pedagoško ponavljanje i potvrdu Bog iznova daje Jakovu novo ime Izrael (Post 35,10), koje svojim značenjem ističe sukladnu misao da je sada na snazi Božje bojevanje, Božji spor i nastojanje, ne više Jakovljeve metode (hebr. jiśra 'el, "borit će se Bog"). ${ }^{24}$ Obnovljeno davanje imena također je razumljiva pouka (usp. Post 32,29). Za noćnoga boja Jakov je najprije morao reći svoje ime (Post 32,28), dana mu je prilika da ispravi nakazno zatajenje vlastite osobe kad je lažno tvrdio »Ja sam Ezav« (Post 27,19). Tek priznavši istinu o sebi, Jakov je postao spreman za nov životni korak. Sada pak, po povratku na korijene, to je riješena stvar (Wenham, 2002b, 325). U Božjem je govoru odmah jasno da je pred njim Jakov (Post 35,10).

23 Izostavlja udaljene vidike obećanja, a usmjerava se na one neposredne u Post 28,15 (Hamilton, 1995, 247).

24 Prijevod slijedi Hamiltona unatoč raspri o značenju, jer se glagol, osim u Post 32,29, rabi jedino u Hoš 12,4 (Hamilton, 1995, 334). 
Novost je očita. Jakov — pohrvatimo li mu ime kao "hvatač pete" — nazvan je tako zato što je već kod rođenja htio preteći brata, hvatajući ga za petu (hebr. āqeb, Post 25,26). ${ }^{25} \mathrm{~S}$ rođenim je bratom trgovao (Post 25), lažno se predstavljao (Post 27). Taj je Jakov po povratku u domovinu spreman za novo ime koje znači da sada njegov životni boj pripada Bogu i da Božje metode vrijede. To je prvi cilj njegova izbjeglištva i selilaštva.

\subsection{Migracija kao lustracija}

\subsubsection{Bijeg od vlastitoga grijeha}

Božji poziv na povratak bitan je i stoga što otvoreno pokazuje pravo stanje stvari: Jakov je, odlazeći iz svojega doma, bio u bijegu. Raskrinkava to Božji govor (brh, "bježati”, Post 35,1), a potvrđuje opis oltara podignutoga Bogu, koji se Jakovu objavio dok je bježao (brh , "bježati”, 35,7). Sam Jakov uviđa da to ne bijaše promišljen, solidno pripravljen iskorak mladića u samostalan život ni odvažan početak životne misije, nego: »dan moje stiske« (hebr. șārâ, 35,3). ${ }^{26}$

Pitamo li zašto migracije započinju, Jakovljev primjer pruža posebno svjetlo. Jakov bježi od vlastitoga brata. Bježi od prijetnje koju je sam izazvao. Opis mikroskopski razotkriva: Pronicljivi je brat Jakov najprije karijeristički iskoristio trenutak Ezavove gladi nakon neuspješna lova (Post 25,31), a potom je definitivno izokrenuo stvari teškom prijevarom i zatajivanjem vlastitoga identiteta. Razumijemo jarost (Post 27,44) i gnjev (45) koji kipe u Ezavu i pretaču se u ekstremnu, radikalnu kainovsku odluku: »Ubit ću svojega brata!« $(27,41) .{ }^{27}$ Odlazak $\mathrm{u}$ inozemstvo samo izliku ima u potrazi za životnom družicom. Tako je to ista dovitljiva majka s ocem diplomatski isposlovala (Post 27,46). Pravi razlog vezan je uz nerealnu nadu da će za »nekoliko dana« (r. 44) izbivanja bijes brata Ezava minuti i da ce prijevara pasti u zaborav.

Jakovljevo izbjeglištvo i migracija u tuđinu bio je njegov put osobnoga pročišćenja. On, koji je varao, lažno uzimljući bratov identitet, doživljava prijevaru s identitetom sestre: umjesto Rahele dolazi Lea (Post 29,23). On koji je trgovinom htio do prvorodstva, doživljava da se s njime trguje, iskorištavan, više puta ljuto prevaren glede plaće (»10 puta«, Post $31,7.41) .{ }^{28} \mathrm{U}$ izbjeglištvu, koje je sam prouzročio, mnogostruko prevareni varalica proživljava svoju osobnu lustraciju.

\subsubsection{Pomirenje s Bogom is bratom}

Koliko god neposredni povod za migraciju bila bratova prijetnja smrću, pa se kao nužnost traži pomirenje s vlastitim bratom, ipak je na putu do bližnjega Jakov najprije imao boj s Bogom (Post 32,22-29). Da bi došao do brata čovjeka,

25 Jakov time bijaše stigmatiziran, kako Ezav ističe u Post 27,36 (Hamilton, 1995, 333).

26 Jakov ima razumljive teškoće u suočavanju sa svojom prošlošću (Hamilton, 1995, 376).

27 Ezav prijeti ubojstvom, ali više nego na Kaina, nalik je Abšalomu, koji je dvije godine smišljao osvetu protiv Amona (Hamilton, 1995, 230).

28 Može biti riječ o simboličnom, zaokruženom broju kao u Post 24,10 i Br 14,22 (Speiser, 2008, 244). 
najprije mora "raščistiti račune" s Gospodinom, ponajviše zacijelo stoga što je s pravom kod prve Božje objave doživio strah i trepet (Post 28,17) ${ }^{29}$ jer se je svetim Božjim imenom bio poslužio za svoju laž. »Jahve mi je pomogao«, lažno je svjedočio ocu Izaku (Post 27,20). Pomirenje s Bogom traži se za pomirenje s čovjekom i vodi do njega.

Pred Bogom treba, vidjeli smo, Jakov priznati tko je, tu valja iznijeti istinu o sebi kako je to bio učinio pred lukavcem Labanom (Post 29,13) koji ga je iskoristio. Jakov mora odgovoriti na pitanje kako mu je ime (hebr. »Što je tvoje ime? «, Post 32,38). ${ }^{30}$ Pred Bogom treba izreći svoju životnu potragu koja još nije dobila odgovora: on traži blagoslov.

I opet, biblijska je "dijalektika" na Jakovljevu primjeru prodorna i nezaustavljiva. Da bi se u miru mogao vratiti svojim korijenima, da bi ondje, gdje je poniknuo, mogao primiti na dar blagoslov, najprije se mora izmiriti s bratom. Silna, "napuhana” diplomacija, povorka s darovima koje šalje ususret bratu Ezavu (Post 32,14-22) najbolje dokazuju da ljuta rana još uvijek peče u dubinama njegova bića, nije zacijelila. ${ }^{31}$ Onaj pravi razlog zbog kojega se iselio još je uvijek tu i žudi za rješenjem. Ništa ne vrijedi što su godine prošle, što je usprkos teškoćama uspješno pokrenuo pozamašan "pogon” i stekao dobara za dva tabora (Post 32,8.11). Ništa ne znači što ima vrlo brojnu obitelj i sada je na čelu velike zajednice, a tek je s jednim štapom bio započeo svoj migrantski put (Post 32,11).

Ishodišni problem čeka na ono dubinski ganutljivo rješenje koje će u Bibliji poprimiti vrhunsko mjesto kao opis milosrdnoga oca u čuvenoj Kristovoj pouci. Suprotno Jakovljevim očekivanjima, Ezav svojemu bratu »trči ususret, prima ga u zagrljaj, ljubi ga « (Post 33,4, usp. Lk 15,20). ${ }^{32}$ Pomirenje je toliko dirljivo da u izvornom hebrejskom tekstu obojica pritom plaču. Jakov može, zbog prethodna iskustva u susretu s Bogom (»lice«, Post 32,31) posvjedočiti koliko to duboko seže jer njemu je pred bratovim licem »kao da vidi lice Božje« (Post 33,10).

\subsection{Svrha migracije: Božje nakane}

Sve je to, međutim, put pročišćenja i priprave, koji napokon dovodi Jakova do toga da, baš kao čovjek kod stvaranja, primi na dar blagoslov (Post 1,28; 5,2; 35,9) i ime koje mu Bog daje (»Adam«, Post 5,2; »Izrael«, 35,10). Time postaje sposoban za novo blisko poznavanje s Bogom. Tek sada Bog mu priopćava svoje ime, koje označava božansku svemoć: »Ja sam El Šadaj«(Post 35,11). Svemogućnost se tu zacijelo ponajprije odnosi na Božju moć kojom je Jakova od iskrivljenih stranputica, lutanja — ne samo prostornoga, geografskoga, nego od početka moralnoga i duhovnoga — konačno doveo onamo kamo pripada. Presudna je to

29 Susret s Bogom donosi strah čovjeku koji spoznaje svoj grijeh, npr. Post 3,10; Izl 3,6; 20,15; Suci 6,23; 13,22 (Wenham, 2002b, 223).

30 Priznavanje staroga imena utire put novomu (Hamilton, 1995, 333).

31 Želi brata udobrovoljiti pa pripravlja kao dar 550 grla stoke (Hamilton, 1995, 325).

32 Razlika je između Ezava koji trči i Jakova koji šepa i još ne zna bratove namjere, a poljubac može ovdje označavati oproštenje (Hamilton, 1995, 344). 
nova blizina s Bogom. Bog mu se predstavlja, a u noćnoj borbi Jakov to nije svojom silom mogao izboriti (Post 32,30). Poznavanje Boga, također je sržni biblijski dar. Riječ je o razumljivom, bitno novom stupnju međusobne bliskosti: sada se obojica po imenu poznaju.

Tek sada, u toj završnoj točki, vrativši se, Jakov je spreman poslušati onu izvornu Božju zapovijed danu čovjeku u obliku blagoslova odmah kod stvaranja (Post 1,28). Božji nalog Jakovu: »Budi rodan!« (Post 35,11) ${ }^{33}$ obnavlja iskonski Božji zahtjev i nakanu s čovjekom da mu život bude plodan, što će u Kristovim riječima dobiti znanu potvrdu i objašnjenje. Pred učenicima Gospodin tumači da ih je izabrao sa svrhom da rod donose, i to trajan rod (Iv 15,16), a prethodno je već pokazao metodu za to, učvršćenu logikom prirode u trsu i lozama: tko u njemu ostaje, taj donosi mnogo roda (Iv 15,5). Jakov je pripravan i za drugi dio prvotne zapovijedi koja hebr. riječju rab ne smjera tek na umnažanje, nego - kako prvi novozavjetni teolog izvrsno tumači - na rast do pune veličine, na dosizanje dostatnosti, a to je »savršen čovjek « po mjeri »uzrasta punine Kristove« (Ef 4,13). Jakovljev pristanak na Božje nakane nije doduše izrečen riječima, ali se očituje u žrtvi lijevanici, koju kao odgovor prinosi (Post 35,14). Kad Bog u svojim nakanama Jakovu najavljuje cijelu zajednicu naroda (Post 35,11), u tekstu stoji znakovita riječ qāhāl, koja je u grčkom prijevodu bila ekklesía - novozavjetni naziv za Crkvu, što cijelom događaju daje dalekosežno proročko značenje. A kad pred Jakovom spominje Izaka (Post 35,12), ${ }^{34}$ to tada naznačuje Jakovljevo izmirenje s roditeljima, s obitelji iz koje potječe.

\subsection{Osvrt na Jakovljev put}

Jakovljev je put iz njegova vidika bio bijeg od bratove prijetnje, a potraga za životnom pratnjom služila je kao formalni razlog. Božja pak nakana s dugotrajnim Jakovljevim izbjeglištvom i selilaštvom od dvadesetak godina (usp. 31,41; Wenham, 2002b, 277) bijaše ne tek spas i potom pomirenje s bratom, nego temeljita osobna lustracija, koja je Jakova konačno dovela do — od početka pogrešnim metodama traženoga - blagoslova. Božji je naum da Jakov počne doista slušati Božji glas, provoditi Božju, ne svoju volju, da primi ono ime koje mu Bog namjenjuje, da upozna Božje ime i postane čovjekom prema onom nacrtu koji je Bog već u stvaranju zadao. Uporište je to koje će omogućiti Jakovu da na kraju života svim svojim potomcima udijeli blagoslov.

\section{Sveta Obitelj u izbjeglišstvu}

Evanđelje bez pridržaja svjedoči o Kristovu selilačkom putu sa Svetom Obitelji. Neugodno iskustvo koje mučno uzdrmava spokoj obitelji usred noćnoga mira

33 Nalazi se na više mjesta u Knjizi Postanka. Činjenica da Jakov već ima brojnu djecu potvrđuje da nije riječ tek o roditeljstvu (Hamilton, 1995, 381).

34 Jakovljevo pomirenje s ocem potvrdu ima u izravnoj vezi Post 35,11 s Izakovim riječima u Post 28,3s (Wenham, 2002a, 325). 
i oni moraju brže-bolje u tuđinu još iste noći (usp. Mt 2,14) ${ }^{35}$ - ne bijaše im prva takva stvar. Zbog administracije rimskoga imperija, po carskoj zapovijedi, morali su oni u zadnjim danima Marijine trudnoće na put u Betlehem. Budući da je to prvi popis za Kvirinija (Lk 2,2), ${ }^{36}$ lako je zamisliti kakva je gužva vladala. Za bračni par koji čeka dijete nema mjesta! Nakon putničkoga napora i nakon tjeskobnoga traženja smještaja, kojima je bio izložen već u majčinoj utrobi, Isus je rođen u štali, položen u životinjske jasle.

Luđački Herodov strah natjerao ih je u tuđinski kraj drevne "Kuće ropstva". Ali i po povratku neće imati mira. Vraćajući se u svoju zemlju, opet nailaze na prijetnju. U Judeji vlada Arhelaj, koji ide stopama preminuloga oca Heroda (usp. Mt 2,22), pa je Sveta Obitelj iznova ugrožena i još jednom mora dalje na put. ${ }^{37}$ Nastanili su se ponovno u Galileji, u Nazaretu.

Nemamo točnih podataka koliko su te selidbe i iseljeništvo trajali, ali očito je da je riječ o čak četiri preseljenja. Što to znači za život obitelji, lako je razumjeti. Ako se u 21. stoljeću susrećemo s raznim napadima na obitelj i njezine osnove, Evanđelje nudi ohrabrenje. Sam Sin Božji svojim je ljudskim životom posvetio obiteljske muke: podložnost administrativnim propisima, bijeg pred zatornikom, život u tuđini i višestruke selidbe.

\subsection{Otac je važan}

Biblijski izvještaj o bijegu u Egipat u prvi plan stavlja lik oca obitelji, koji je — kako se često ističe - u novijoj europskoj kulturi zatajio. Sv. Josip, poočim Isusov, pažljiv je na Božju riječ. U snu prema biblijskoj tradiciji glasnik mu Božji progovara. Može Josip biti “na istoj valnoj dužini” s Marijom kad i on prepoznaje, prima anđela i razumije njegov jezik. Pažljivost Josipova na duhovni život vidljiva je u četiri puta ponovljenu slušanju Božje pouke i naredbe »u snu « (Mt 1,20; 2,13.19.22). ${ }^{38}$ Ne samo da je na riječ anđela uzeo k sebi svoju ženu (usp. Mt 1,24), nego je dvaput na izričitu zapovijed: »Ustani, uzmi dijete i majku njegovu!« (Mt 2,13.20) odmah reagirao. Što u snu čuje, na javi spremno čini.

Poslušan je, čuje oba puta zahtjevan nalog — najprije: »Bježi u Egipat! « (Mt 2,13), pa potom »Pođi u zemlju Izraelovu!«(r. 20). Odmah, u idućem biblijskom retku (r. 14.21), bez odlaganja, proveo je Božju zapovijed: spremno opet vodi svoju obitelj. ${ }^{39}$ Josip je aktivan. Odmah se daje u akciju, ako treba i usred noći. Čini ono što Gospodin traži. Koliko je predan Božjoj volji, vidi se u strpljivu čekanju na nov poziv: ostat će ondje dok mu anđeo ne kaže (usp. Mt 2,13). Nije dosta jednom poslušati nebeski govor, valja iz dana u dan pozorno pratiti Riječ.

35 Teške okolnosti za obitelj i Josipov posluh prisutne su također već u Mt 1,24 (Hendriksen 1973, 177).

36 Ima teškoća oko točnoga datiranja (Fitzmyer, 2008, 401).

37 Povijest bilježi da je strah bio opravdan pa su ga Rimljani uklonili s vlasti (Hagner, 2002, 39).

38 Izravna objava otkriva Božje nakane u Mt, tako i kod Pilatove žene (Albright i Mann, 2008, 8).

39 I forma teksta - idući je redak odraz prethodnoga - u oba slučaja ističe poslušnost Josipovu (Hagner, 2002, 39). 
Poput prvoga, drevnoga biblijskoga pravednika Noe, Josip se očito dobro razumije sa svojim Gospodinom jer mu ne treba ni riječi razjašnjavanja. Ne prigovara, ne gubi se u razglabanju, ne opravdava se, ne mora ništa dodatno pitati. Šutke čini. Obavijen plaštem svete tišine čini Božja djela za svoju Svetu Obitelj.

\subsection{Raskrinkano herodovsko načelo}

Koliko je stvar ozbiljna i žurna vidi se u tom što upravo Josip, koji ima ulogu oca u Svetoj Obitelji, prima upozorenje o Herodovoj zlobi. Božji mu glasnik objavljuje Herodovu paklensku nakanu. Dvaput Josip čuje o opakom "traženju". Premda je u tajnim pregovorima Herod podlo najavio: »Poklonit ću mu se « (Mt 2, 8), on traži da upropasti ${ }^{40}$ dijete (r. 13), »traži dušu « djeteta, i u tom nije sam — opisuje izvorni evanđeoski jezik (»oni«, r. 20). Umjesto da upravlja povjerenom mu zajednicom, kralj ispunjen bijesom (»silno se rasrdi«, r. 16), daje nemilosrdno posmicati mušku malenu djecu do dobi od dvije godine po cijelom betlehemskom kraju. ${ }^{41}$ Evanđelje piše da pritom Herod »šalje« (grč. apostéllo), potvrđujući još jednom njegovo izopačeno, svetogrdno prisvajanje Božje vlasti i zloporabu autoriteta.

Bijeg Svete Obitelji u Egipat vezan je uz trostruku utjehu. Josip naime ne sluša samo o teškim herodovskim prijetnjama kojima je izvrgnuta njegova obitelj, nego anđeo odmah najavljuje i Herodov »kraj«, njegovo »skončanje« (usp. Mt 2,15.20) koje će doći: umrijet će (r. 20). ${ }^{42}$ Anđelov poziv nije usmjeren samo na spašavanje djetetova života, nego znači da Sin Božji preuzima na sebe povijest Božjega naroda. Njegovo Utjelovljenje obuhvaća i razdoblje u "Kući ropstva" i sveti izlazak koji je starozavjetna slika Otkupljenja. Gospodin iz Egipta doziva svojega sina (usp. Hoš 11,1; Mt 2,15), kao što ga je iz groba, u koji ga ljudski grijeh odvodi, dozvao. Davno je Gospodin izrazio svoju želju da ga i "Egipat" — ta iskonska slika neprijatelja koji udara na život Božjega naroda — upozna (hebr. jd ', Izl 14,4.18; usp. Durham, 2002, 187). Sada, evo, sam Isus onamo dolazi. Anđeo Gospodnji može i u Egiptu Josipu progovoriti (Mt 2,19). Zlobnu "Kuću ropstva” Bog pohađa, razotkriva paklenske spletke i njihov kraj, štiti Svetu Obitelj.

\section{Zaključak}

Kao i za biblijski narod Božji, za nas suvremene Europljane nova seoba naroda, susret sa strancima i tuđom kulturom pokazuju tko smo i kako smo odgojeni, prigoda su da se vratimo kršćanskim korijenima koji su nadahnjivali oce osnivače naše Unije. Korjenita su kušnja koja treba očitovati našu vjernost Isusu Kristu, Gospodinu. Ovaj rad jasno je naznačio kako za fenomen migracija presudnu ulo-

40 Grč. glagol apolesai najavljuje izvještaj o muci, gdje se opet pojavljuje u Mt 27,20 (Albright i Mann, 2008, 35).

41 To je u skladu s poznatim Herodovim karakterom (Albright i Mann, 2008, 19).

42 Upravo Herodova smrt pomaže točnom datiranju Kristova rođenja i utvrđivanju kronologije Novoga zavjeta (Albright i Mann, 2008, 23). 
gu imaju vjera i odnos prema Bogu, pa ih razumna politika nipošto neće zanemariti. Hrvatska ima osobitu ulogu zbog svojega stoljetnoga živoga iskustva s kulturom pravoslavlja i islama. Jedino uz načelne, u vjeri ukorijenjene poglede, prihvaćajući Božje vodstvo povijesti pojedinih osoba i naroda, prepoznat ćemo pozitivno gibanje kojim Bog ostvaruje svoje naume.

Već primjer Abrahama, ističući najviše koliko su važni razlog zbog kojega i svrha radi koje nastaju migracije, upozorio je kao i kod sv. Josipa u Novom zavjetu, na potrebu duhovnoga rasuđivanja, prepoznavanja istinskoga Božjega zova, koji traži korjenito odvajanje od načela Babilonske kule i kralja Heroda. Jakovljev izbjeglički i selilački put prije svega je pokazao kako je u Bibliji bitan povratak, a sam migrantski pothvat ponajviše se očitovao kao proces osobnoga obraćenja od trgovanja i laži. Primjer Svete Obitelji pokazao je k tomu kako selilaštvo i izbjeglištvo u prvi plan stavljaju ulogu oca i traže brigu za obitelj koja je izvrgnuta napadu.

Kristov životni put, kojim prihvaća na sebe sudbinu Božjega naroda te posvećuje i boravak u "Kući ropstva" i Izlazak — put u Obećanu zemlju, dovodi napokon do zaključne misli kako selilaštvo i izbjeglištvo u Svetom pismo predstavljaju priliku za otkrivanje istine o Isusu Kristu, poziv su na sjedinjenje s njime, svrha im je, štoviše, u tom da pružaju prigodu za prihvaćanje Otkupitelja.

\section{Literatura:}

Albright, William Foxwell; Mann, C. S. (2008). Matthew: Introduction, translation, and notes. London: Yale University.

Biblija. Stari i Novi zavjet (2002), Glavni urednici: J. Kaštelan, B. Duda, Zagreb: Kršćanska sadašnjost.

Durham, John I. (2002). Exodus. Dallas: Word, Incorporated. [Edicija: Word Biblical Commentary, WBC, sv. 3.]

Elliott, John Hall (2008). 1 Peter: A new translation with introduction and commentary. London: Yale University.

Fitzmyer, Joseph A. (2008). The Gospel according to Luke I-IX: Introduction, Translation, and Notes. London: Yale University.

Hagner, Donald A. (2002). Matthew 1-13. Dallas: Word, Incorporated. [Edicija: Word Biblical Commentary, WBC, sv. 33a.]

Hamilton, Victor P. (1990). The Book of Genesis. Chapters 1-17. Grand Rapids, MI: Wm. B. Eerdmans Publishing Co. [Edicija: The New International Commentary on the Old Testament.]

Hamilton, Victor P. (1995). The Book of Genesis: Chapters 18-50. Grand Rapids, MI: Wm. B. Eerdmans Publishing Co. [Edicija: The New International Commentary on the Old Testament.]

Hendriksen, William (1973). Exposition of the Gospel According to Matthew. Grand Rapids: Baker Book House. [Edicija: New Testament commentary, sv. 9.]

Hrvatski program Vatikanskog radija (2018). U 2018. godini ubijeno više od $3000 \mathrm{kr}$ šćana, više nego 2017. godine. Vatican News, 26 prosinca 2018. URL: https://www. vaticannews.va/hr/crkva/news/2018-12/sveti-stjepan-krscani-mucenici-vise-nego2017-godine.html (06.09.2019.) 
LG. Lumen genitum (1970). Drugi vatikanski koncil, Dogmatska konstitucija Lumen genitum o Crkvi. U: Josip Turčinović (ur.), II vatikanski koncil: Dokumenti: Latinski $i$ hrvatski (str. 91-204). Zagreb: Kršćanska sadašnjost.

Speiser, E. A. (2008). Genesis: Introduction, Translation, and Notes. London: Yale University.

Stuart, Douglas (2002). Hosea, Joel, Amos, Obediah \& Jonah. Dallas: Word, Incorporated. [Edicija: Word Biblical Commentary, WBC, sv. 31.]

Watts, John D. W.(22005). Isaiah 34-66. Nashville: Thomas Nelson [Edicija: Word Biblical Commentary, WBC, sv. 25.]

Wenham, Gordon J. (2002a). Genesis 1-15. Dallas: Word, Incorporated. [Edicija: Word Biblical Commentary, WBC, sv. 1.]

Wenham, Gordon J. (2002b). Genesis 16-50. Dallas: Word, Incorporated. [Edicija: Word Biblical Commentary, WBC, sv. 2.]

Migrants and Refugees in the Holy Scriptures

Niko Bilić*

\section{Summary}

In exploring the biblical approach to the issue of migrants and refugees, this paper first ascertains that the character of the People of God is that of the pilgrim. The examples of Abraham (Gen. 12) and St. Joseph in the New Testament point out the need for spiritual discernment in recognizing a genuine call from God. Thus, the purpose of the migration is to bring blessings to the peoples, and the cause of the migration is the need to leave behind pride and misunderstanding, the biblical tower of Babel. The path of migration taken by Jacob renders his return essential (Gen. 35). His migration is explained as a personal purification process, conversion and reconciliation with God and his brother Esau, which enables Jacob to adopt the original concept from Genesis 1 as God's creation. The Holy Family in the role of the migrant family highlights the task of the father and his need to protect his family. Their experience ensures that migration is one possible way to accept the Redeemer and to follow in his path.

Key words: Jesuit Refugee Service; reason for migration; return; Abraham; Jacob; the Holy Family

* Niko Bilić, Ph.D., Senior Assistant Professor, Faculty of Philosophy and Religious Studies, University of Zagreb. Address: Jordanovac 110, 10000 Zagreb, Croatia. E-mail: nbilic@ffrz.hr 